Antonio Dávila Pérez

\title{
St. Jerome versus Sanctes Pagnino in the Reception and Inquisitorial Process of the Polyglot Bible of Antwerp (1568-1577) ${ }^{1}$
}

\section{Sv. Hieronim vs. Sanctes Pagnino v recepciji in inkvi- zitorskem procesu Biblia Polyglotta iz Antwerpna (1568-1577)}

Abstract: The controversial reception of the Polyglot Bible of Antwerp (1569-1573) was a result of the religious conflict of Post-Tridentine Europe between the rigorist defenders of the Vulgate of St. Jerome, who fiercely attacked this new Bible, and the Hebraists, who claimed the value of the sources even to correct the mistakes of the Vulgate. The Polyglot of Antwerp, edited by the most prominent Hebraists of the moment, was printed with the Latin column of St. Jerome. However, the editors also published the translation of the Hebraist Sanctes Pagnino, after revising it, within the Apparatus Sacer, the last three volumes of the Bible that included all sorts of instruments for studying the Sacred Text. This was one of the main reasons why the immediate reception of the most critical Bible of the $16^{\text {th }}$ century stirred up so much controversy that it became subject to an inquisitorial process in 1577 . In the present contribution, this polemic reception is studied mainly in light of what new texts recently published on that process tell about the philological and theological confrontation of different translations of the same biblical passages made by St. Jerome, on the one hand, and by Sanctes Pagnino, on the other one.

Keywords: Biblical Scholarship, Humanism, Benito Arias Montano, León de Castro, Juan de Mariana

This work is part of the Research Project of the National R\&D Plan PGC2018-094604-B-C31 (MCIU/IEA/ ERDF, EU), and has been done in the context of the Network of Excellence „Europa Renascens: Biblioteca Digital de Humanismo y Tradición Clásica (II): España y Portugal“ (FFI2017-90831-REDT), funded by the Government of Spain. With this article we want to contribute to a philological line of research on the Hebrew Bible that has already produced valuable fruits in recent numbers of this scientific journal (see, for instance, Krašovec 2019 and Petrović 2019). 
Povzetek: Kontroverzna recepcija Večjezične biblije iz Antwerpna (1569-1573) je bila sad verskih nasprotij v Evropi po tridentinskem koncilu med zagovorniki Hieronimove Vulgate, ki so to novo Sveto pismo ostro napadali, in pa ,hebraisti', ki so cenili hebrejski izvirnik in so želeli popraviti napake v Vulgati. Večjezična biblija iz Antwerpna, ki so jo pripravili najboljši tedanji strokovnjaki za hebrejščino, je vsebovala tudi stolpec Hieronimovega latinskega besedila, poleg tega pa je bil znotraj oddelka Apparatus Sacer, ki je obsegal zadnje tri knjige in je vključeval različna orodja za preučevanje svetega besedila, natisnjen tudi izboljšani prevod hebraista Sanctesa Pagnina. To je bil eden glavnih razlogov, da je recepcija najpomembnejše izdaje Svetega pisma 16. stoletja vzbudila toliko kontroverz in postala celo predmet inkvizitorskega procesa leta 1577. Članek opisano obravnava z vidika nedavno objavljenih besedil glede procesa v zvezi z njihovimi filološkimi in teološkimi argumenti glede razlikovanja v prevodu sv. Hieronima in S. Pagnina.

Ključne besede: biblicistika, humanizem, Benito Arias Montano, León de Castro, Juan de Mariana

\section{Introduction}

In the history of Biblical Scholarship, one of the episodes that best exemplify the tensions between Theology and Philology is the controversial reception of the Polyglot of Antwerp, the essential edition of the Bible in the $16^{\text {th }}$ century (Biblia Sacra 1569-1573). Around this Polyglot, two opposing groups of scholars clashed again: on the one hand, the strict defenders of the Vulgate of St. Jerome, who attacked this new Bible fiercely; on the other, the Hebraists, who claimed the value of the sources even to correct the Vulgate in those passages needing revision.

The project of the Polyglot of Antwerp (1569-1573) was born as a re-edition of the Complutensian Polyglot of the beginning of the century (Vetus Testamentum 1514-1517). However, during the time elapsed from the first Polyglot to the second, the conflict between the defenders of the Vulgate and the Hebraists was gradually deteriorating. The turning point in this controversy was marked by the fourth session of the Council of Trent, April 8, 1546, which promulgated the well-known Decretum de editione et usu sacrorum librorum. This decree placed the Vulgate -by considering it as the , authentic' version-above all the Latin translations of the Sacred Books. The primary purpose of this decree was to put control on the new Latin translations based on the originals. However, a radical interpretation of the decree led some biblical scholars even to defend Vulgate's superiority over the original biblical texts.

Since the beginning of the new Polyglot editorial project, the main reason for discussion was which Latin translation should be printed in the column next to the Hebrew text of the Old Testament. The first proofs sent by the printer Christopher Plantin from Antwerp to Madrid dared to replace the text of the Vulgate, which was the one printed in the Complutensian, by the more literal Latin translation of the Hebraist Sanctes Pagnino, published for the first time in 1527 (Habes in hoc libro 1527). The Spanish authorities rejected the proposal. Finally, the Polyglot of Antwerp 
was printed with the Latin column of Saint Jerome - as it was in the Complutensian Polyglot - but the editorial team of the Bible would not allow the new Polyglot to lack a literal Latin translation and, although they had no official instruction in this regard, they published Pagnino's translation, revised and amended. It was not located in the columns of the first five volumes dedicated to the biblical text, but within the so-called Apparatus Sacer, the final three volumes that included all kinds of instruments for studying the Bible. The simple coexistence of Pagnino's translation with that of St. Jerome in the new Bible was reason enough for the attacks against this edition to arrive even before the first sheet was printed. In Spain, the main enemy of the Polyglot was the professor of Greek at the University of Salamanca León de Castro, who had also managed to imprison in 1572 his colleagues of the same university fray Luis de León, Martín Martínez Cantalapiedra and Gaspar de Grajal on the very same grounds, a fact that shook the European Theology².

The volume of the entire preceding bibliography on the reception of the Polyglot is enormous. It allows following the conflicting parties' movements very well since the printing of the last volume of the Biblia Regia in 1573 until the beginning of the inquisitorial lawsuit against this work in 1577. Nevertheless, the recent edition of new texts related to the three actors of the process (prosecution, defence and censorship) has allowed us to connect these writings with other texts already published, reconstruct some unpreserved texts, and achieve a better comprehensive knowledge of that relevant inquisitorial lawsuit. To put it simply, the centrepiece of the lawsuit was a cluster of twenty-four passages of the new Latin translation of the Old Testament published in the Polyglot, based on Santes Pagnino's version, that distanced themselves from the corresponding translations of St. Jerome and that, according to the complainant, obscured the prophetic sense that the Catholic Church had traditionally seen in those same passages of the Vulgate. This article analyzes the connection between all the texts of the inquisitorial process collected to date with the primary objective of shedding light on the three passages of the new Latin translation of the Old Testament published in the Polyglot of Antwerp that were denounced and finally condemned due to its deviation from the translations offered by the Vulgate of St. Jerome.

\section{The Immediate Reception of the Polyglot Bible in the Light of a New Document (HSA B 1351)}

Scholars working on Humanism are fortunate that, from time to time, one may come across still unpublished and valuable documents. This is the case of an apology of the Biblia Regia written in Spanish by its director Benito Arias Montano, of which the Spanish bibliographer Nicolás Antonio gave vague news in the $17^{\text {th }}$ century: in particular, Antonio referred to a manuscript of this apology or defence that was sacked by the English army in the Spanish city of Cádiz and taken to

On the process of Luis de León see the recent edition of Alcalá Galve 2009. The documentation on the two other inquisitorial processes can be found in Pinta Llorente 1935; 1946. 
the University of Oxford at the end of the $16^{\text {th }}$ century (Antonio $1783,1,210$ ). This manuscript promised to be a key piece to rebuild the reception of the Royal Bible, and, for this reason, a long series of researchers has unsuccessfully tried to locate this document in the libraries of Oxford since the $17^{\text {th }}$ century (Dávila Pérez 2016). Some scholars have even considered it a non-existent work (Morocho Gayo 1998, 260-261). However, fortunately, such is not the case.

In 2019 I published a book with the first critical and annotated edition of this text, which is titled Defensión y respuesta de la traslación latina ad u[er]bum del hebreo que está en el segundo tomo del Sacro Apparato de la Biblia Real. The only copy I have come across is not the one supposedly preserved in Oxford (a testimony that, if it still exists, I have not been able to locate yet), but in the Hispanic Society of New York. ${ }^{3}$ The description of this manuscript already appeared in the catalogue Iter Italicum of Paul Kristeller with the abbreviated title -and with a typographical error-of Defensión y respuesta de la traslación latina ad abum (sic) ${ }^{4}$ del hebreo. After reading this manuscript, the sound conclusion can be drawn that this is the same document called "Apology" by previous scholarship because its content fits perfectly with the little that was known to us about the content of that ,lost' apology, namely, a complete account (according to Arias Montano's version) of the reception of the Polyglot Bible; as well as the answers to each of the objections of the enemies of the Polyglot, in particular of León de Castro. ${ }^{5}$ Nevertheless, the most critical reachable conclusion is that this Defensión y respuesta was the exact text presented by Arias Montano as self-defence for the lawsuit initiated by the Spanish Inquisition in 1577; that is, it is the same defensive writing that Juan de Mariana had before his eyes to elaborate his inquisitorial report. Moreover, the primary evidence is that Juan de Mariana, in his handwritten censorship document, which is still unpublished, ${ }^{6}$ responds to Arias Montano's allegations following the same order and structure in which they can be read in the manuscript of the Hispanic Society.

\section{The Genetic Circle of Accusatory Writings: The Accusation on Job 19,25-26}

The Defensión y respuesta of Arias Montano provides us with new information on the movements of León de Castro during the reception of the Polyglot. It should be highlighted here that, during the entire period after the publication of the Polyglot, its director showed eagerness, as it is natural, to know the exact content of the accusatory writings of León de Castro. These writings have not been located yet, in case they are preserved. Nevertheless, the Defensión y respuesta provides

With the reference HSA Ms. B 1351.

4 Instead of the abbreviation ad u[er]bum; see Kristeller 1963-1992, V, 319.

5 This fully coincides with what the first librarian of the Bodleian wrote on the content of the manuscript of the Apology taken by the English army to Oxford at the end of the $16^{\text {th }}$ century; see James 1612, III, 43.

6 Io[hannis] Marianae censura in Biblia Regia quae nuper diligentia et industria D. Benedicti Ariae Montani in lucem edita sunt (Biblioteca Apostolica Vaticana, Ms. Barb. Lat. 674, ff. 14r-66r). 
essential information in this regard since it allows us to reconstruct how many accusatory writings there were, their title, and their main content.

According to one crucial passage of this new text, ${ }^{7}$ there were, in total, three writings of accusation. The first two contained general questions, and, as Arias Montano criticizes, they came to repeat ideas from the commentaries on the prophet Isaiah published by Castro in 1570 (Castro 1570). Castro's thesis could be summed up in the idea that the Jews had intentionally corrupted the Hebrew original text of the Bible in the passages of the Old Testament that could be understood as a prophecy of Jesus Christ. The accuser's final claim was that the literal translators of the Hebrew Bible had to correct the Hebrew original text, allegedly corrupt, so that their translations coincided with the Hebrew text that St. Jerome seemed to have followed in the Vulgate. The point that Arias Montano makes linking Castro's accusation with a work already published seems to me of great interest. The reality is that, as we will see, all the writings that formed part of the Inquisitorial dossier of the Biblia Regia (those of the defender, of the prosecutor and the censor) were finally reused by their authors in later printed publications. Moreover, that happened even though, in principle, the whole inquisitorial process and its materials should be kept secret.

In his third and final accusatory writing, now in Latin, León de Castro compiled a list of twenty-four passages of the new Latin literal translation of the Old Testament included in the Polyglot that demonstrated, in his opinion, the Judaizing character of the new Bible. In this text, the primary evidence of the accusation can be found, and, therefore, this is the writing to which Arias Montano responds most directly in his Defensión y respuesta. The content of Castro's specific accusations can be reconstructed based on the responses of Arias Montano and the censorship of Juan de Mariana.

For example, let us examine one of the denounced passages, perhaps the most important: Job 19,25-26. ${ }^{8}$ The Vulgate reads as follows: ${ }^{9}$ "Scio enim quod redemptor meus uiuit, et in nouissimo die de terra surrecturus sum: et rursum circundabor pelle mea, et in carne mea uidebo Deum meum. " (Biblia Sacra, VII, f. [Cc 6r], p. 35. $)^{10}$ ( For I know that my redeemer lives, and in the last day I shall rise out of the earth: and I shall be covered again with my skin, and in my flesh, I shall see my God. «) According to the Catholic Church, this passage was one of the most evident testimonies of the resurrection of the flesh. Let us now check the new Latin translation of the Biblia Regia, based on Pagnino's version: „Et ego noui redemptorem meum uiuum et nouissimo super puluerem staturum. Et postquam

7 In Defensión y respuesta (HSA Ms. B 1351, ff. $3^{\mathrm{v}}-4^{\mathrm{r}}$ ); see edition in Dávila 2019, 33.

8 In the Defensión y respuesta... this passage is discussed in the accusations number 5 (HSA B 1351, f. $5^{v}$, edited in Dávila 2019, 53-55) and number 19 (HSA B 1351, f. 7r , edited in Dávila 2019, 77-78).

9 When quoting the Vulgate, I follow the edition of Colunga Cueto and Turrado Turrado 1983. The reason for this choice is the fact that in the texts of the process of the Polyglot Bible of Antwerp, the passages quoted from the Vulgate are closer to the state of the text that was consolidated in the Sixto-Clementine edition of 1592 than to the text of St. Jerome that appeared in the Polyglot of Antwerp, heir of which was published in the Complutensian Polyglot. All the translations of the Latin texts in this article are mine.

10 My references to the Polyglot Bible of Antwerp correspond to the copy kept in the Library of the University of Granada with the signature BHR/Caja IMP3-022. 
pellem meam contriuerint hanc, et de carne mea uidebo Deum. " ("But I know that my redeemer is alive, and at the end, he will stand on the dust. Even after my skin has been destroyed, yet I shall see God in my flesh. «) Leon denounced that this new translation completely confused the idea of the resurrection and followed the interpretation of the Jews. His main arguments were the following: first, on the assumption that the Jews had corrupted the Hebrew original text of the Bible, Castro proposes to change a letter in the Hebrew text in order to read iakim (surgam or surrecturus sum, "l shall rise", as translated in the Vulgate) instead of iakum (resurget, "he will stand ", the meaning accepted in the new Latin literal translation of the Polyglot Bible); second, the Hebrew word naquaf does not only mean ,to cut' or ,to destroy' (contriuerint, in the literal Latin translation of the Polyglot Bible) but also ,to cover' or ,to enclose' (circundabor, as St. Jerome translated). The censor Juan de Mariana declared that the proposal of changing the original Hebrew text of the Bible could not be admitted without the consensus of the Catholic Church; despite that, he finally agreed with León de Castro that the new Latin translation of this passage published in the Polyglot had to be corrected since it completely deformed the mystery of the resurrection of Christ. ${ }^{11}$

We have already said that Castro's accusatory writings have not been located yet. However, I have been able to verify that the majority of the passages denounced by Castro in the process of the Polyglot Bible were collected, explained, and developed in a later publication of 1585 with the title Apologeticus ${ }^{12}$ where, by the way, there is no reference to the inquisitorial lawsuit (Castro 1585). ${ }^{13}$ This closes, therefore, the genetic transit of texts that have been pointed out here. In the case of the accusation, Castro's postulates started from their commentaries on Isaiah published in 1570; they materialized in the form of the specific denunciations in the three accusatory writings of the process of 1577, and, finally, many of those accusations of the process came to light in the Apologeticus of 1585.

11 Io[hannis] Marianae censura in Biblia Regia (ff. 30v-31v $; 42^{r}-43^{r}$ ).

12 León de Castro, Apologeticus pro lectione apostolica et euangelica pro Vulgata diui Hieronymi, pro translatione LXX uirorum, proque omni ecclesiastica lectione contra earum obtrectatores (Salmanticae, Matthiae Gastii, 1585).

13 The specific pages of the Apologeticus where many of the passages already denounced in the process of 1577 are analyzed are the following: Ps. 9,1 (p. 547); lob 19,26 (pp. 353-354); lob 19,27 (pp. 355-256); Is. 16,1 (pp. 279-281); Dan. 9,26 (pp. 334-338); Dan. 9,27 (pp. 336 and 666-667); Hab. 2,3 (pp. 554-555); Hab. 2,4 (pp. 555-556); Is. 1, 9 (pp. 162-164); Is. 9,1 (pp. 638-642); Os. 11,1 (pp. 621-622); lob 19,25 (pp. 352-353); Ps. 8,1 (pp. 331-332); Is. 11,1 (pp. 626-629); Ps. 79(80),1 (p. 74); Ps. 21(22),17 (pp. 343-344); Ps. 15(16),10 (pp. 486-488); Ps. 8,3 (pp. 664-666 and 674-675); and Ps. 15(16),9 (pp. 483-484). Some of the preceding biblical passages and others not included in the Apologeticus had already been discussed by Castro in his Commentaria in Isaiam Prophetam of 1570: that is the case of Is. 16,1 (pp. 334-335); Is. 1,9 (pp. 22-24); Is. 9,1 (pp. 212-215); Is. 10,22 (pp. 263-266, not studied in Apologeticus); Is. 28,10-11 (pp. 476-482, not studied in Apologeticus); and Is. 11,1 (pp. 273-283). 


\section{From the Defence of the Polyglot Bible to the Apology of the Hebrew Studies: The Omission of the Accusation on Ps. 21(22), 17}

Let us now turn again to the defence. The new manuscript titled Defensión y respuesta located in the Hispanic Society of America has already been considered in the previous lines, focusing on its transmission and primary content. Here I will approach two later texts that seem to be genetically dependent on the Defension y respuesta. The first one is a manuscript from the Spanish National Library entitled De Hebraicorum Bibliorum uaria scriptione et lectione atque de uario interpretum instituto animaduersio. ${ }^{14}$ I did not know any previously printed witness of this manuscript before my recent edition (Dávila 2019, 88-105); this document is a working draft, and intermediate textual material between the Defensión y respuesta and a later text of Arias Montano titled Benedicti Ariae Montani de uaria Hebraicorum Librorum scriptione et lectione commentatio. This Commentatio is a prologue of eleven pages published in the re-editions of the successful seventh volume of the Polyglot of 1584 and subsequent years (Biblia Hebraica 1584). ${ }^{15}$ The text was printed only seven years after Mariana's censorship. It included the same contents of the Animaduersio (mainly dealing with the philological peculiarities of the Holy Tongue) followed by a wide selection of León de Castro's objections to Pagnino's translation and Arias Montano's responses, which, as has been said before, came from the Defensión y respuesta of the inquisitorial process. By the way, Arias Montano, like León de Castro in his Apologeticus, does not reference the inquisitorial process in his publication, nor does he quote Castro by name.

Unlike the Defensión y respuesta, the printed Commentatio is written in Latin, the answers to Castro's accusations are much more elaborated, and one can perceive in this publication the filter that was the censorship of Juan de Mariana. Thus, in Ps. 21(22),17, the Vulgate presents Saint Jerome's translation: "quoniam circumcederunt me canes multi; concilium malignantium obsedit me. Foderunt manus meas et pedes meos " ( for many dogs surrounded me: the council of the malignant has besieged me. They have dug my hands and feet «). According to the Catholic Church, this text was a prophecy of the death of Christ on the cross. The new literal Latin translation of the Biblia Regia reads as follows: "Quoniam circuncederunt me canes, coetus malignantium circuncederunt me: quasi leo manus meas et pedes meos" (Biblia Sacra, VII, f. [Ee 2], p. 52) ("for many dogs surrounded me, a gang of evil men crowded around me; like a lion, my hands and feet «). The phrase, like a lion' came from a bizarre variant of the original Hebrew text (caari or sicut leo instead of caru or foderunt). Furthermore, that was different from that of the Hebrew text of the Complutensian and the one accepted by Saint Jerome and the foremost Hebraist scholars of the moment. In his censorship of the Polyglot, Mariana proved that Castro was right and strongly recommended

\footnotetext{
14 Reference Ms. 149, ff. 120'-123r .

15 The Commentatio appears on $\left.\mathrm{ff}^{+{ }^{+r}-[+\dagger} 6\right]^{\mathrm{r}}$.
} 
to correct this translation, ${ }^{16}$ and I think that was why Arias Montano directly removed this accusation in his printed text of $1584 .^{17}$

\section{The Manuscript Inquisitorial Report and Its Later Printed Reuse: The Third Condemned Passage (Ps. 15[16],10)}

Mariana's censorship of 1577 also has an engaging genetic-textual transmission. The first testimony, in chronological order, is a letter in Spanish from Juan de Mariana to the General Inquisitor in Spain written in August 1577, in which he informs the reader that he has concluded the censorship and makes a valuable summary of it. ${ }^{18}$ The entire censorship is in Latin, it is a document still unpublished, signed in September 1577, and the only testimony I know is the copy, with some mistakes, preserved in the Vatican Library. Nevertheless, just as the two parts of the lawsuit did, Mariana also wanted to take advantage of the papers he wrote for this important occasion. In 1609 the Jesuit published a brief treatise entitled Pro editione Vulgata (Mariana 1609, 34-126). Suppose that the still-unpublished censorship document is compared with this printed publication. In that case, it becomes evident that what Mariana did was to reproduce and adapt most of his inquisitorial report on the Biblia Regia by adding new materials and modifying some formal aspects.

Nevertheless, Mariana confesses that his writing comes directly from his activity as an informant of the lawsuit between Arias Montano and León de Castro in any place of this printed treatise. Mariana instead refers to the general controversy on the authority of the Vulgate, and his words also perfectly apply to the inquisitorial processes of the famous Hebraists of Salamanca. Moreover, Mariana even quotes in his printed treatise the names of Castro and Arias Montano in the places where he also cited them in the censorship document, but he also manages to avoid all those passages of the handwritten censorship document where he speaks of himself as the censor. One may ask how it is possible that Mariana cites the arguments of the two parts of a secret inquisitorial lawsuit and, at the same time, can hide his role as censor. He could safely do it because Castro's complaints and Arias Montano's responses were already of public knowledge after the impression of the Apologeticus of the first and the Commentatio of the second.

Mariana admits that he had more inclination to defend than to condemn as far as the censorship content is concerned. Despite this, the Jesuit severely assesses both Leon de Castro and Arias Montano. As to the first one, the censor condemns his excess of rage, the contradictions and lies of some of his anti-Hebrew argu-

16 Io[hannis] Marianae censura in Biblia Regia, ff. $44^{\mathrm{v}}-45^{\mathrm{r}}$.

17 In contrast to the other two passages studied in this article, that, despite Mariana's negative report, were also included in the printed Commentatio. See, on Job 19,24-25, Dávila 2019, 154-157 and 188191; as to Ps. 15(16),10, see Dávila 2019, 196-199.

18 A complete copy of the letter is preserved in the Royal Library of Sweden in Stockholm Ms. A 902, ff. 91'-94r and has been edited by Macías Rosendo 1998, 464-468. 
ments, and he even refuses Castro's core claim: no one can correct the original Hebrew text of the Bible without the consensus of the Catholic Church. ${ }^{19}$ As to Arias Montano, Mariana criticizes the little appreciation he gave to the Vulgate and urges him to correct three passages of his new Latin translation of the Bible: two of them have already been examined here, namely, Job 19,24 and Ps. 21(22),17. The third is Ps. 15(16),10. ${ }^{20}$ Here the Vulgate translated: "Quoniam non derelinques animam meam in inferno, nec dabis sanctum tuum uidere corruptionem « (»Because you will not leave my soul in hell, nor will you give this holy one to see corruption «); the Catholic Church interpreted the passage as an announcement of the resurrection of Christ, whose body did not experience corruption. The new literal translation of the Polyglot of Antwerp reads as follows: "Quoniam non relinques animam meam in sepulchro: non dabis misericordem tuum uidere foueam " (Biblia Sacra, VII, f. [Eer], p. 49.) ("Because you will not leave my soul in the grave: nor will you allow your merciful one to see the pit«). The main arguments of the censor against this new translation were the following. The primary meaning of the Hebrew word seol, according to the censor, was ,hell', as in the Vulgate, and not ,grave' or sepulchre, translation with which the new Bible fell on the side of the heretics, who deny that Jesus descended into hell. On the other hand, when translating the Hebrew word sahhath as foueam (,pit') instead of the generally admitted (by the Catholic Church) meaning of corruptionem (,corruption'), Arias Montano followed Judaizing interpretations and made it difficult to understand the passage as a prophecy of the resurrection of Christ, since the Messiah was buried, that is, he saw the pit or the grave..$^{21}$

\section{Conclusions}

This paper intends to show that the reception and inquisitorial process of the Polyglot Bible of Antwerp consisted in a philological and theological confrontation over the centuries between St. Jerome and the defenders of the Vulgate, on the one hand, and Sanctes Pagnino and his Hebraist followers, on the other hand.

During the inquisitorial lawsuit against the Biblia Regia in 1577, the close precedent of the processes and imprisonment of the Hebraists professors at the University of Salamanca in 1572 was always alive. First, Leon de Castro himself also operated in the denunciations against his colleagues in Salamanca. Second, the principles of the accusations against them were similar to those that Castro presented years later against the Polyglot Bible: the contempt for the Vulgate of Saint Jerome and the preference for the rabbinic interpretations of Pagnino, Vatable, and others in passages of the Old Testament that announced the arrival of Jesus

19 See, especially, the first chapter of Mariana's censorship document titled „Nemini licere priuata auctoritate Hebraico Diuinae Scripturae castigare“; in Io[hannis] Marianae censura in Biblia Regia, ff. 21v-23r.

20 Mariana also discussed the three condemned passages studied in this article within the chapter titled "De nouis uersionibus" of his treatise Pro editione Vulgata (1608, 114-119).

21 Mariana's censorship on this passage can be read in lo[hannis] Marianae censura in Biblia Regia, ff. $30^{v}-31^{v}$ and ff. $60^{v}-62^{v}$. 
Christ. This point becomes more plausible if it is taken into account that even several specific passages of the Vulgate alleged by Castro in the process of the Polyglot Bible had already been used by himself against the professors of Hebrew at Salamanca. That is the case, for instance, of two important passages studied in the present article: Job $19,24^{22}$ and Ps. 15(16),10. ${ }^{23}$

The three parties involved in the inquisitorial lawsuit of 1577 (prosecution, defence and censorship) produced, in different phases, a series of writings in Latin and Spanish genetically linked to each other. The edition and in-depth examination of the genetic thread from the manuscripts of the process until its printed reuse is the purpose of my research projects underway.

\section{References}

\section{Primary sources}

Biblia Sacra Hebraice, Chaldaice, Graece et Latine Philippi II Regis Catholici pietate et studio ad Sacrosanctae Ecclesiae usum. 1569-1573. 8 vols. Antwerp: Christophorus Plantinus.

Castro, León de. 1585. Apologeticus pro lectione apostolica et euangelica pro Vulgata diui Hieronymi, pro translatione $L X X$ uirorum, proque omni ecclesiastica lectione contra earum obtrectatores. Salamanca: Matthiae Gastii.

- - - 1570. Commentaria in Esaiam Prophetam ex sacris scriptoribus Graecis et Latinis aduersus aliquot commentaria et interpretationes quasdam ex rabbinorum scriniis compilatas. Salamaca: Mathias Gastius.

Colunga Cueto, Alberto, and Laurentio Turrado Turrado, eds. 1983. Biblia Vulgata: Biblia Sacra iuxta Vulgatam Clementinam. Madrid: BAC.

Habes in hoc libro prudens lector utriusque Instrumenti nouam tranlationem aeditam. 1527. Lugdunum: per Antonium du Ry, impensis Francisci Turchi et Dominici Berticinium et lacobi de Giuntis bibliopolae.

James, Thomas. 1612. A Treatise of the Corruption of Scripture, Councils, and Fathers, by the Prelats, Pastors and Pillars of the Church of Rome, for Maintenance of Popery: Together with a Sufficient Answer unto James Gretser and Anthony Possevine, Jesuits and the Unknown Author [May, a Priest] of the Grounds of the Old Religion \& the New; Divided into Five Parts. London: Mathew Lownes.
Vetus Testamentum multiplici lingua nunc primo impressum /.../ Nouum Testamentum Graece et Latine in Academia Complutensi nouiter impressum /.../. 1514-1517. 6 vols. Academia Complutensi: Industria Arnaldi Guilielmi de Brocario, sumptibus F. Francisci Ximenez de Cisneros.

\section{Secondary sources}

Alcalá Galve, Ángel. 2009. Proceso inquisitorial de fray Luis de León. Salamanca: Junta de Castilla y León.

Antonio, Nicolás. 1783. Bibliotheca Hispana noua siue Hispanorum scriptorum qui ab anno 1500 ad 1584 floruere notitia. 2 vols. Madrid: Joaquín de Ibarra.

Dávila Pérez, Antonio. 2016. La apología de la Biblia Regia escrita por Benito Arias Montano: un documento en paradero desconocido. Euphrosyne 44, no. 1:279-290.

- - . 2019. Benito Arias Montano: Apología de la Biblia Regia. Alcañiz-Lisboa: CEC.

Krašovec, Jože. 2019. God's Justice between Punishment and Forgiveness in the Hebrew Bible. Bogoslovni vestnik 79, no. 4:877-890.

Kristeller, Paul Oskar. 1963-1992. Iter Italicum: A Finding List of Uncatalogued or Incompletely Catalogued Humanistic Manuscripts of the Renaissance in Italian and Other Libraries. 6 vols. London: The Warburg Institute; Leiden: Brill.

Macías Rosendo, Baldomero. 1998. La Biblia Políglota de Amberes en la correspondencia de

22 Which also appeared in the process of Luis de León; see Alcalá Galve 2009, 324, 330, 332. 
Benito Arias Montano: MS. Estoc. A 902. Huelva: Servicio de Publicaciones de la Universidad de Huelva.

Mariana, Juan de. 1609. Tractatus VII, nunc primum in lucem editi. Coloniae Agripinae: sumptibus Antonii Hierati, sub Monocerote.

Morocho Gayo, Gaspar. 1998. Avance de datos para un inventario de las obras y escritos de Arias Montano. Ciudad de Dios 211, no. 1:179275.

Petrović, Predrag. 2019. The Christological Aspects of Hebrew Ideograms. Bogoslovni vestnik 79, no. 4:1027-1038.
Pinta Llorente, Miguel de la. 1935. Procesos contra los catedráticos hebraístas de Salamanca: Gaspar de Grajal. Madrid: Monasterio de El Escorial.

- - - 1946. Proceso criminal contra el hebraísta salmantino Martín Martínez Cantalapiedra. Madrid: Instituto Arias Montano. 